\title{
Glasbeno delo čitalnic na Slovenskem do ustanovitve Glasbene matice $(1848$ - 1872)
}

Namen magistrske naloge o zgodnjem obdobju čitalnic na Slovenskem, ki ga je slovenska muzikološka misel že označila kot glasbeno "čitalništvo", je bil dvoplasten. Po eni strani je skušala obogatiti informacijsko vsebino $\mathrm{z}$ novimi podatki o delu čitalnic iz doslej še nepregledanih arhivskih in časopisnih virov, po drugi strani pa osvetliti dogajanje pod podatkovno vrhnjo s poudarjenim socialnozgodovinskim izhodiščem. Se pravi, $v$ nasprotju $\mathrm{z}$ glasbeno imenentnim zgodovinopisjem, ki glasbo obravnava avtonomno, $v$ povezavi $z$ družbenimi in političnimi okoliščinami v slovenskem etničnem prostoru, je naloga želela pojasniti: prvič, kako so primarno vplivale zunajglasbene okoliščine na glasbeno življenje in delo, in drugič, kako so se zrcalile v ustvarjalnih dosežkih.

Uvodna razmišljanja osvetljujejo te okoliščine, ki so vplivale na slovensko glasbeno delo tretje četrtine prejšnjega stoletja. Fenomen "čitalništva" pojasnjujejo idejni, motivni in žanrski zgledi (nemški in češki) ter neposredne glasbene osnove pri nas, $z$ drugega zornega kota pa oris mesta in pomena slovenske posvetne glasbene dejavnosti sredi 19. stoletja, funkcij, ki jih je imela glasba, položaja glasbenikov in recepcije glasbe. Glasbeno delo čitalnic na Slovenskem moremo pravilno presojati le, če pojasnimo tudi vlogo Janeza Bleiweisa, ki je takrat krojil vse družbeno in kulturno življenje ter programa Zedinjene Slovenije. Z glasbenega stališča je bilo potrebno osvetliti delo Gregorja Riharja, ki je bilo vzor ne samo ustvarjalcem prvega ampak tudi drugega čitalniškega kroga.

Osrednji poglavji sta namenjeni organizaciji in delu Slovenskega društva (njegov pomen $v$ glasbenem oziru zrcalijo izdaje Slovenske gerlice in besede) ter čitalnic. Razvrstitev v dve časovni skupini se je zdela smiselna zaradi komplementarnosti zgodovinskih in glasbenih dogodkov. Delo prvega čitalniškega kroga glasbenih 
ustvarjalcev je bilo povezano predvsem $z$ delovanjem Slovenskega društva (le-to je bilo ustanovljeno 1848), delo drugega pa s čitalnicami, ki so jih po letu 1861 začeli ustanavljati na Slovenskem. Mejna letnica je zgolj okvirna, saj gre prej kot za dogodke za razliko v duhovnem ozračju, ki je spodbujalo ustvarjalce. Glede na regionalno specifiko je bilo gradivo razdeljeno po posameznih deželah. Faktografski zapisi o čitalnicah, ki so na voljo, so v preglednicah dodani na koncu naloge. Omejujejo se na letnico nastanka, število članov in predsednika, podatke o prireditvah in pevskem zboru. Podobo glasbene prakse čitalnic dopolnjuje pregled sporedov in izvajalcev glasbenega dela prireditev.

Idejna izhodišča in značilnosti ter pregled tvornosti in dosežkov Jurija Flajšmana, Miroslava Vilharja in delno Kamila Maška $s$ kasnejšim ustvarjanjem Antona NedvÏda, Davorina Jenka, Gustava Ipavca in Antona Hajdriha je bilo izhodišče za primerjavo dela obeh generacij v sklepu naloge.

Pojasniti je bilo potrebno tudi v dosedanjih razpravah premalo opaženo mentorsko in organizacijsko delo Gašparja Maška, sopotnika prve generacije ter upoštevati zgodnja dela vodilnih osebnosti slovenske glasbene romantike: Benjamina Ipavca, Frana Gerbiča in Antona Foersterja, ki so bili na vsak na svoj način povezani s čitalnicami.

Spremembe v delovanju čitalnic je konec šestdesetih let 19. stoletja prinesla diferenciacija njihove kulturne dejavnosti, posamezni odseki so prerasli v samostojna društva. Najprej se je to zgodilo v Ljubljani, kjer so 1867 ustanovili Dramatično društvo, potreba po profesionalizaciji glasbenega dela pa je dozorela $\mathrm{z}$ ustanovitvijo Glasbene matice leta 1872. Njun vpliv na glasbeno delo ljubljanske Narodne čitalnice je pojasnjen v naslednjem poglavju.

Pri vrednotenju dosežkov prvih dveh generacij ustvarjalcev in glasbenega dela čitalnic je bilo $\mathrm{v}$ zaključku potrebno upoštevati, da glasba kot umetnost na Slovenskem ni imela možnosti avtonomnega razvoja. Zaradi specifike okoliščin (družbenopolitičnih, socialnih in glasbenih) avtonomni umetnostni kriteriji niso relevantni. $Z$ naše glasbenozgodovinske perspektive so bile uglasbitve $v$ nacionalnem (slovenskem) jeziku takrat aktualne, v luči razvoja slovenske glasben pa pomenijo osnove samobitni slovenski glasbeni ustvarjalnosti. Čeprav sta bila volja in talent mnogokrat močnejša od zmožnosti in rezultatov, je vendarle tudi v glasbenem oziru zaslediti razvoj od skromnih, s pomanjkljivim znanjem zapisanih pesmi do "pravega" štiriglasnega moškega zbora, kantate, od igre s petjem do spevoigre.

Kdaj in zakaj je "čitalniško" glasbeno ustvarjanje postalo stranski tir, ki ni vodil več nikamor, bo mogoče bolje pojasniti s preučevanjem tega dela po letu 1872. Torej je magistrska naloga lahko tudi uvod $v$ raziskovanje naslednjih desetletij čitalniškega dela.

Obranjeno 8. maja 1997 na Filozofski fakulteti v Ljubljani. 


\section{Musical Activity of Reading Societies in Slovenia until the Founding of the Musical Centre (1848 - 1872)}

The purpose of the M.A. thesis on the early period of reading societies in Slovenia, which has already been designated in Slovene musicological pursuits as musical "reading societies", is twofold. On the one band it seeks to enrich the already available information with new particulars about the activity from as yet unexamined archival or newspaper sources, and on the other to elucidate the development under the data level by focusing on the socio-bistoric point of departure. Which is to say that in contradistinction to the musically immanent bistoriography which treats music in an autonomous way, related to social and political circumstances in the Slovene etbnic area, the thesis sets out to clarify: first, bow did primarily external-musical developments affect musical life and work, and second, how were they reflected in creative achivements.

The introductory thoughts center on the circumstances influencing the Slovene musical activity of the third quarter of the previous century. The phenomenon of "reading societies" is elucidated by conceptual, motivic, and genre examples (German and (zech) and by our own direct musical elements, and from the other point of view by a description of the position and of the significance of the Slovene secular musical activity in the middle of the 19th century, of the functions performed by music, of the status of musicians, and of the reception of music. The musical activity of reading societies operating in Slovenia can be appropriately assessed only if we account also for the role of Janez Bleiweis, who was at that time shaping the entire social and cultural life, and for the programme of United Slovenia. From the musical point of view it was necessary to shed light on the work of Gregor Ribar, who was a model for creative musicians not only of the first but also of the second circle of reading societies.

The central two chapters deal with the organization and work of the Slovene Society (its importance in musical respect is manifest from issues of the Slovene Turtledove and academies) and of reading societies. The classification into temporal groups appeared sensible owing to the complementary nature of bistorical and musical events. The work of the first reading society circle of musical authors was connected above all with the activity of the Slovene Society (which was founded in 1848), while the activity of the second with reading societies, which were started in Slovenia after the year 1861. The border year is simply provisional for the real concern is focused not on the events but on the difference in the spiritual climate which stimulated creativity. With regard to regional specifics, the material was classified according to individual countries. Factographic notes about the reading rooms that are available are added in survey tables at the end of the thesis. They are limited to 
the year of beginning, the number of members, and the chairman, to information about events and the chorus. The picture of the practical musical activity carried on in the reading society is complemented by a survey of programmes and performers of the musical part of events.

Conceptual starting points and surveys of the activity and acbievement of Jurij Flajšman, Miroslav Vilhar, and partly of Kamilo Mašek together with the later work of Anton Nedvĕd, Davorin Jenko, Gustav Ipavec and Anton Hajdrib represented the point of departure for the comparison of the work of the two generations in the concluding part of the thesis.

It was necessary to shed light on the so far insufficiently noticed mentorship and organizational work of Gašpar Mašek, a fellow traveller of the first generation and to take into account early works by the leading figures of Slovene musical romanticism: Benjamin Ipavec, Fran Gerbič, and Anton Foerster, who were each in bis own way connected with reading societies.

The changes in the activities of reading societies were towards the end of the 19th century brought about by the differentiation of their cultural pursuits; individual sections had grown into independent societies. This was to happen first in Ljubljana, where in 1867 the Dramatic Society was founded, and the need for the professionalisation of musical work led to the founding of the Musical Centre in 1872. Their influence on the work of the National Reading Society in Ljubljana is accounted for in the following chapter.

In the evaluation of the achievements of the first two generations of musical authors and of the musical work carried on in reading societies it is in the conclusion necessary to take into account that in Slovenia music as art bad no possibility for autonomous development. Owing to specific circumstances (socio-political, social, and musical ones) autonomous art criteria are not relevant. From our musical and bistoric perspective the setting of works in the national (Slovene) language to music was at that time of topical importance, and in the light of the development of Slovene music they represent the basis of original Slovene musical creativity. Even if the will and the talent were frequently more powerful than the abilities and the results, one can nevertbeless also in musical respect trace a progression from modest songs, written down with insufficient skills, to a "true" four-part male chorus, cantata, from a play with incidental singing to a musical comedy.

When and why did the musical creativity of "reading rooms" become a siding no longer leading anywhere will possibly be answered through the study of this activity after the year 1872. Hence the M.A. thesis can be also be but an introduction to the examination of the following decades of the activities of reading societies.

Defended on May 5, 1997, Philosopbical Faculty, Ljubljana. 